\title{
Study on the Information Management Paths for College Education in Network Era
}

\author{
Yijie Qi \\ College of Horticulture, Jilin Agricultural University, Changchun, 130118 \\ qyj101@126.com
}

Keywords: Network Era; College Management; Information Management; Education; Paths

\begin{abstract}
New technology revolution develops rapidly with information as the symbol, which asks higher requirement on the information management on college education. So, colleges take advantage of science and technology to continually improve education mechanism, management paths. The innovation of colleges should not only lie in education, but also resource integration among education and scientific researches so as to gradually improve the innovation of network management as well as information management construction to finally contribute to cultivate talents which can adapt to the society.
\end{abstract}

\section{Introduction}

College education cultivates high-quality talents for the society. So, in the information era, colleges should catch the opportunity and keep pace with time to seek for innovation; change the traditional pattern and recognize the talent requirement in knowledge-based economy age; construct education information management platform; integrate current education management information system; perfect the regular education management mechanism to shape an information management environment for the development of students. In the future, information management should become the mainstream in colleges, which should also be the only way to develop.

\section{Existing Problems of College Education Management in Network Era}

To begin with, college education does not pay attention to network management and at present a glittering array of colleges are still adopting the class management mode. Students go to a certain class, which is same to the management mode in middle school and will kill the individual personalities of students because everyone is different, asking for different information. Therefore, in education management, colleges should break the class management mode to encourage students to develop their personalities and choose what they are really interested in. In the network era, students have many accesses to information and education managers do not have a sense consciousness to fully take advantage of network technology, which is not conducive to cultivate information talents. In addition, in order to win talent resources in fierce competition, improve the employment rate and fame, most of colleges invest on human resources, materials and funds, ignoring the information management. What's more, relevant departments do not encourage perfecting the management system and mechanism, which is bad for developing a systematic management.

Secondly, network information resources construction cannot keep time with the time. Concerning the college education information management, resource management should be the fundamental one, however, most colleges do not highlight this point and the information construction is lagging behind. First, relevant departments do not carry out guidance and do not communicate with each other. Second, colleges do not share resources and do not cooperate without criteria. Third, departments inside colleges lack communication and departments work separately. So, some of colleagues repeat doing the same thing and do not update timely. As a result, the information development is not accurate enough and will bring problems for data sharing. Furthermore, education information does not have information code rules, which should be suitable 
for both the past and future usage. While collecting students information, we have to pay attention to accuracy and science to avoid resource replication.

Thirdly, there is an information system issue of education management. In the network era, the software of college education information management should realize long-distance management, which is complicated in terms of function, technology, and investment and operation cycle, taking a long time. To develop information management system, code staffs are required and they have to be familiar with the operation condition of college, and they better be experienced college management workers. Moreover, there is problem we have to know is whether the colleges are qualified in terms of both software and hardware condition and whether they have proper mechanism. For most colleges, they adopt the way of combining introduction and development. They save time and costs via introduction and the introduced software can work quickly. At the same time, re-development should be carried out based on real condition to create information management features.

Fourthly, the information quality of faculties is poor. In the network era, college education management should not only relay on advanced software and technology because objects are students while teachers are managers. So, we have to improve the information quality of managers to let them be equipped with modern teaching philosophy; adopt scientific means to carry out management to continually accumulate management experience and innovation level. Managers are direct participants and executors of management, so their information quality affects the overall information management mode of colleges. However, many managers are not professional and they just rely on their experience. They used to adapt to the education but now, they are no longer adapted to the modern needs and are not able to cultivate modern talents because they have a poor ability to deal with information technology and some of them cannot even use it.

\section{Information Management Paths for College Education}

Firstly, accelerate the information construction process. The information management of colleges needs cooperation among different departments so as to realize teaching information share. Even though students are those who are being managed, they still have to improve their information awareness. That is to say, we have to encourage all of them to participate in the information management to improve their network awareness. Concerning students' information quality, colleges can pay attention to course setting, especially computer information technology course to create information management atmosphere. In addition, colleges should be prepare to take a long time to implement it because information campus construction needs a long time. In addition, colleges should timely know the factors which will affect the information construction. Based on students' personalities, colleges should construct different information management system based on different talents cultivation targets.

Secondly, colleges should construct a network information platform. The management department of colleges should adopt modern means to better improve the management efficiency as well as quality to reduce workload. Via information platform, colleges are able to know the education condition, problems the first time so that they can timely come up with solutions. What's more, the monitoring, decision and information feedback will all be able to check. The network information platform will also help students to improve themselves. Based on the digital information resources, students can choose their interested ones, which will have diverse information. Furthermore, college managers should timely update and maintain the information of network information platform so as to ensure the accuracy and keep it with time. Only by doing this, can we better improve the information management of colleges?

Thirdly, adhere to the concept of people-orientation to create an atmosphere of encouragement. The objects of college information management are students and comparing to social laws, college regulations have distinctiveness and their main responsibility is education. Therefore, college management should adhere to people orientation to encourage students and fully discover students' potential. Only in the environment which is scientific, democratic and free, can students grow more healthily. The information management should implement from the perspective of profession 
arrangement, talents cultivation mode, education mode and course settings to respect opinions of teachers and respect the personality of students.

Fourthly, perfect the regulations of college information management. Only by formulating strict and operable regulations which can adapt to the information era and health development of students, can we ensure the implementation of education management and realize prefect procedure and standard. In addition, colleges should regularly modify and perfect regulations to ensure the coordination of scientific regulation and information management. While perfect various regulations, we can take advantage of information data as well as relevant software and schools can perfect their management system based on the overall system, which will help to improve the autonomy of various schools. Furthermore, schools have to establish information management system for educational administration, set up a education guidance center, information center, registration center and quality supervision center to improve the monitoring and feedback capability. Finally, concerning teaching management, we should focus on macro-control and out more attention to education informationization.

Fifthly, strengthen the team construction of information management team. To improve the information quality can help to improve the informationization process of colleges. In addition, to realize the all-round development should be the target of college informationization, and therefore teachers and education managers should focus on the information management team construction. To begin with, colleges can regularly train teachers and organize activities to carry out communication with other colleges. In addition, college teachers should continually improve themselves; get rid of the traditional teaching mode; set modern education philosophy; take the initiative to learn network information techniques; take advantage of innovative teaching mode, realizing that their responsibility is not only teaching but also participating in information management. Teachers directly contact with students and they have more opportunities and time to understand students and communicate with students to know what they are thinking about so as to add some interesting stuff in class. Furthermore, colleges should build a management team with strong responsibility and information quality. At the same time, teachers should master advanced maintenance technology to keep the information system and timely deal with the information system. Colleges should also carry out training in terms of professional management to ensure scientific knowledge and encourage them to further their study abroad to learn advanced experience. While recruiting employees, colleges have to be very strict and raise the standard to enroll experienced ones, which is of pivotal importance to the development of colleges and information management improvement.

\section{Conclusions}

The information management construction for college education in network era takes a long time and is tough with a series of problems. Employees and teachers of various departments in colleges should establish the information management concept to establish a network information management platform to perfect regulations based on the concept of people-orientation. Based on this, we can fully take advantage of various information resources and excellent conditions to lay a foundation to realize the information and scientific management, to cultivate professional talents who are urgently needed by the society.

\section{References}

[1] Wang Bangxiong. Reflection on the information management for college education [J]Science $\&$ Technology Progress and Policy

[2] Wang Sheng. Brief study on the college information education construction [J] China Education Innovation Herald, 2009,20.

[3] Yang Minghui, Wan Aiguo, Sun Ning. Discussion on solution of informatization construction in colleges [J] Guangdong Communication Technology, 2009,7. 
[4] He Hui. Study on the current condition and countermeasures for the information system construction in colleges [J] Science and Management, 2009,3.

[5] Ye Shuyan. Islanding Phenomenon and solutions for the information construction in colleges [J]China Science and Technology Review, 2009,17.

[6] Han Fengyi. Discussion on the construction and development of information management for college education [J]. Education forum, 2011(31):246-247.

[7] Cai Tingting. Problems and policies of information management construction for college education : take Tianjin Foreign Studies University, Binhai Foreign Service Institute as example[J].

[8] Western Quality Education, 2016, 2(8):30.

[9] Zhao Guodong. Colleges in information era: Information development and enlightenment of higher education in America Modern Educational Technology, 2003, (5):11-6.

[10]Zhang Wenfeng. Research reviews on higher information survey in the recent decade [J]. Liaoning Education Research, 2007, (8).

[11] Shen Peihua. Tasks for constructing digital campus and information management Educational Informationization, 2001, (11):7-11.

[12] Jiang Dongxing. The development condition and countermeasures for information development. China Information Times9 term 20-23, 2011

[13]Dou Lili. College information construction application based on cloud computing, China High Technology Enterprises, 2011-08, 51-52 